Animal Health Research Institute.

Port Said Laboratory, Food Hygiene,

\title{
OCCURRENCE OF STAPHYLOCOCCUS AUREUS IN FAST FOOD WITH SPECIAL REFERENCE TO ITS ENTEROTOXIGENICITY
}

(With 4 Tables)

By

AMANY M. SHALABY and EMAN M.S. ZAKI*
* Bacterial Toxins Unit, Animal Health Research Institute, Dokki

(Received at 2/2/2008)

تواجد الميكروب المكور العنقودى الذهبي فى الوجبات السريعة مع أشارة

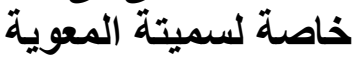

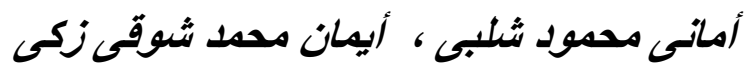

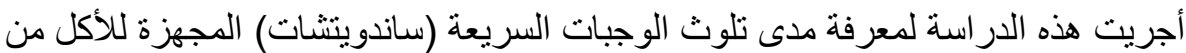

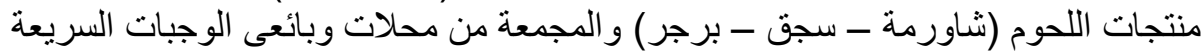

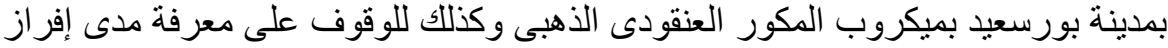

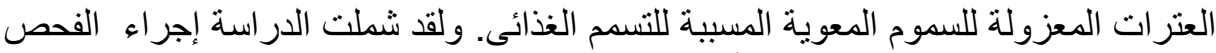

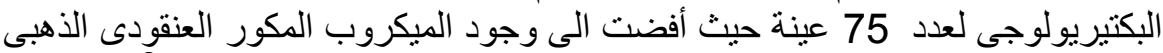

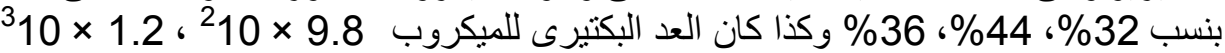

، 8.3 ×

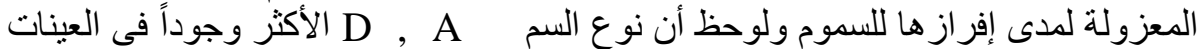

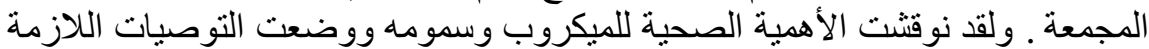
لسلامة المستهلك و والمنتج.

\section{SUMMARY}

A total of 75 random samples of fast food (ready-to-eat meat sandwiches) represented as 25 each of shawarma, sausage and beef burger were collected from various fast food restaurants and vendors on the street in Port Said city. S. aureus could be detected in 32, 44 and $36 \%$ of the analyzed samples with a mean value of $9.8 \times 10^{2} \pm 0.12 \times$ $10^{2} ; 1.2 \times 10^{3} \pm 0.24 \times 10^{2}$ and $8.3 \times 10^{2} \pm 0.09 \times 10^{2} \mathrm{CFU} / \mathrm{g}$ shawarma, sausage and beef burger, respectively. Out of 8 strains obtained from shawarma, only 3 were enterotoxigenic belonging to type A enterotoxin. Five $S$. aureus were enterotoxigenic obtained from sausage samples, 2 of 
them were type $\mathrm{A}$ and the other 3 strains were enterotoxins $\mathrm{AD}$. Furthermore, 4 strains identified as 2 type $\mathrm{AB}$ producers and 2 type $\mathrm{ABCD}$ producers were isolated from beef burger samples. The results showed that enterotoxin A (SEA) was the most frequently in all the examined ready-to-eat-sandwiches followed by enterotoxin type D (SED), indicating that $S$. aureus had a potential public health significance in fast food.

Key words: Fast food, shawarma, sausage, beef burger, staph aureus

\section{INTRODUCTION}

In Egypt as in many other African countries, fast foods are commonly vended on streets and at market sites in urban area where there is constant and heavy movement of people. Although there are no readily obtainable epidemiological data about the risks of food borne diseases resulting from these foods, the laboratory data show that street vended foods frequently have high microbial populations and occasionally high population of pathogenic bacteria (Bryan, 1988 \& 1992).

Nowadays, meat products consumed as sandwiches of shawarma, sausage, beef burger, etc. are commonly prepared and sold by many restaurants which are widely distributed all over the country (Takeaway). Staphylococcus aureus is one of the most important microorganisms which can contaminate or recontaminate cooked foods via workers hands, equipments or utensils (Bryan, $1978 \&$ 1988). The primary reservoirs of $S$. aureus are human skin and mucosa especially the nasopharyngeal cavity (Bystron et al., 2005).

Staphylococcal food poisoning resulting from the growth of enterotoxigenic strains of $S$. aureus in food leading to the production of enterotoxins which is considered one of the major causes of food borne disease all over the world (Minor and Marth, 1972).

Enterotoxins are groups of single chain protein (poly peptides) with molecular weight 28.000- 35.000 Daltons resistant to high temperature (heat stable) and proteolytic enzymes. The enterotoxigenic strains of $S$. aureus produce several types of enterotoxins (A, B, C, D and $\mathrm{E}$ ) which can cause symptoms of intoxications such as vomiting, diarhoea and abdominal cramping (Korpysa et al., 2005). Enterotoxin A (SEA) is responsible for a majority of staphylococcal food poisoning whereas enterotoxin B (SEB) is rarely involved (Robbins et al., 1974). 
In addition most outbreaks as recorded by Halpin-Dohnalek and Marth (1989) resulted from the combined effect of contamination of the food with $S$. aureus often through unsanitary handling, and holding the food at the wrong temperature thus allowing growth and synthesis of enterotoxins. However, the enterotoxication generally is not lethal and the elderly are more susceptible than younger individuals. The amount of enterotoxin necessary to cause intoxication is very small about 94$184 \mathrm{ng}$ (Erol and Iseri, 2004).

Therefore, the purpose of such investigation is to record the occurrence of $S$. aureus in some different fast meat food and its ability to produce enterotoxins.

\section{MATERIALS and METHODS}

\section{Collection of samples:}

A total of 75 random samples of fast meat food were purchased from different fast food restaurants and vendors on street in Port Said city. The samples were represented as 25 each of ready-to-eat shawarma, sausages and beef burger sandwiches. The samples were directly transferred to the laboratory in an ice box under hygienic conditions without delay to be examined bacteriologically.

\section{Preparation of the samples:}

According to the technique recommended by APHA (1992), ten grams of each meat product sample only without bread were put into the stomacher bag, to which $90 \mathrm{ml}$ of sterile physiological saline $(0.9 \%)$ were aseptically added to provide dilution of $1 / 10$, then the content of the bag was stomached for $60 \mathrm{sec}$, using the stomacher, then 10 fold serial dilutions were prepared.

\section{Determination of $S$. aureus count:}

Staphylococcus aureus count/g was determined using surface plating technique according to FAO (1992). $0.1 \mathrm{ml}$ from each of the previously prepared decimal dilutions was transferred onto duplicate plates of Baird- parker media, supplemented with egg yolk tellurite and incubated at $37^{\circ} \mathrm{C}$ for $24-48 \mathrm{hrs}$. Then the black and shiny colonies greater than $1 \mathrm{~mm}$ in diameter with narrow white margin surrounded by clear zone extending into opaque medium were counted and recorded.

\section{Isolation and Identification of $S$. aureus $($ FAO, 1992):}

Suspected colonies of $S$. aureus were subcultured on slants of brain heart infusion agar (Oxoid) (FAO, 1992) and incubated at $37^{\circ} \mathrm{C}$ for $24 \mathrm{hrs}$. Isolated purified strains were identified microscopically and 
biochemically for confirmation according to Flandrois and Carret (1981), Marchant and Parker (1983) and Bailley and Scott (1990).

5. Production and detection of enterotoxins from the isolated strains of $S$. aureus:

a- Production of staphylococcal enterotoxins from the isolated strains:

The isolated strains of $S$. aureus were examined for their ability to produce enterotoxins using Sac culture method (Donnelly et al., 1967).

\section{b- Detection and typing of enterotoxins:}

According to Oda et al. (1979) and Shingaki et al. (1981), detection and typing of enterotoxins were done using serological test by reversed passive latex agglutination technique using Oxoid SET- RPLA (kit used for the detection of staphylococcal enterotoxins A, B, C and D).

6. Detection of staphylococcal enterotoxins in the food samples (Direct extraction):

a- Toxin extraction: the steps including preparation of the food samples and toxin extraction from the food itself described by the method recommended by Park and Szabo (1986) were followed.

b- Enterotoxin detection: as mentioned previously methods recommended by Oda et al. (1979) and Shingaki et al. (1981) was followed using SET- RPLA kit in which antibody- coated latex particles are visibly agglutinated in the presence of SET (Staphylococcal Enterotoxins). It is commercially available in kit form Oxoid Ltd (Basing stoke, Hampshire, UK).

\section{RESULTS}

Table 1: Incidence of S. aureus in the examined fast food samples.

\begin{tabular}{|l|c|c|c|}
\hline \multirow{2}{*}{ Fast food samples } & No. of examined samples & \multicolumn{2}{|c|}{ Positive samples } \\
\cline { 3 - 4 } & & No. & $\%$ \\
\hline Shawarma & 25 & 8 & $32 \%$ \\
\hline Sausage & 25 & 11 & $44 \%$ \\
\hline Beef burger & 25 & 9 & $36 \%$ \\
\hline Chi square & & & 2.00 \\
\hline Probability & & & $0.368 *$ \\
\hline
\end{tabular}

* Non significant 
Table 2: Statistical results of $S$. aureus count /g of the examined fast food samples.

\begin{tabular}{|l|c|c|c|}
\hline Fast food samples & Min. & Max. & Mean \pm S.E. \\
\hline Shawarma & $2 \times 10^{2}$ & $3.0 \times 10^{3}$ & $9.8 \times 10^{2} \pm 0.12 \times 10^{2} \mathrm{a}$ \\
\hline sausage & $1 \times 10^{2}$ & $3.4 \times 10^{3}$ & $1.2 \times 10^{3} \pm 0.24 \times 10^{2} \mathrm{a}$ \\
\hline Beef burger & $2 \times 10^{2}$ & $2 \times 10^{3}$ & $8.3 \times 10^{2} \pm 0.09 \times 10^{2} \mathrm{a}$ \\
\hline F-calculated & & & $11.357 \#$ \\
\hline
\end{tabular}

Mean of the positive samples.

\# Significant at $\mathrm{P}<0.05$ using ANOVA test.

a, b unsignificant difference between similar litter at $\mathrm{P}<0.05$ using Duncan Multiple Range Test.

Table 3: Frequency distribution of the examined fast food samples based on their $S$. aureus count.

\begin{tabular}{|c|c|c|c|c|c|c|}
\hline \multirow{2}{*}{ Intervals } & \multicolumn{5}{|c|}{ Frequencies in different fast food samples } \\
\cline { 2 - 7 } & \multicolumn{2}{|c|}{ Shawarma } & \multicolumn{2}{c|}{ Sausage } & \multicolumn{2}{c|}{ Beef burger } \\
\hline $10-10^{2}$ & - & - & 1 & 9 & - & - \\
\hline $10^{2}-10^{3}$ & 5 & 62.5 & 4 & 36.4 & 6 & 66.6 \\
\hline $10^{3}-10^{4}$ & 3 & 37.5 & 6 & 54.5 & 3 & 33.3 \\
\hline Total & 8 & 100 & 11 & 99.9 & 9 & 99.9 \\
\hline
\end{tabular}

Table 4: Incidence of enterotoxigenic S. aureus and types of its enterotoxins.

\begin{tabular}{|l|c|c|c|c|c|c|c|c|c|c|}
\hline Fast food & \multirow{2}{*}{$\begin{array}{c}\text { No. of } \\
\text { strains } \\
\text { tested }\end{array}$} & \multicolumn{2}{|c|}{$\begin{array}{c}\text { Enterotoxigenic } \\
\text { strains }\end{array}$} & \multicolumn{6}{|c|}{ Types of enterotoxins } \\
\cline { 3 - 11 } & 8 & 3 & 37.5 & 3 & - & - & - & - & - & - \\
\hline Shawarma & 11 & 5 & 45.5 & 2 & - & - & - & - & 3 & - \\
\hline Sausage & 9 & 4 & 44.5 & - & - & - & - & 2 & - & 2 \\
\hline Beef burger & & & 0.884 & & & & & & & \\
\hline Chi square & & & $0.643^{*}$ & & & & & & & \\
\hline Probability & & & & & & & \\
\hline
\end{tabular}

* Non significant

\section{DISCUSSION}

The results in Table 1 revealed that $S$. aureus was present in 32, 44 and $36 \%$ of shawarma, sausage and beef burger sandwiches, statistically there are no significant difference between the three ready to eat meat products. 
It is obvious from such incidence that the level of contamination by $S$. aureus in the examined samples was relatively high, since these fast food are ready-to-eat in the form of sandwiches without any further heat processing. In this respect Wieneke (1974) isolated S. aureus (32-36\%) from cooked foods including meat and she added that $S$. aureus strains isolated from human resembled those from cooked foods. While, Halpin-Dohnalek and Marth (1989) stated that outbreaks of $S$. aureus food poisoning are most often associated with processed red meats and most outbreaks resulted from the combined effects of contamination of the food with $S$. aureus, often through unsanitary handling and holding the food at the wrong temperature thus allowing growth and synthesis of enterotoxins by the pathogen. Alkanahl and Gasim (1993) found that cooked foods (both unheated and reheated) were associated with more incidents of food borne illness cases (56\%) than uncooked foods $(20 \%)$, S. aureus was found in both cooks and suspect foods. It was also found high $\%$ of the cooks associated with food borne incidents had no health certificates.

Regarding the incidence of $S$. aureus recorded in Table 1, the obtained results were less than those obtained by El-Daly (1983); ElSherbeeny et al. (1985); Alkanahl and Gasim (1993); Kumar et al. (2001) and higher than those obtained by Soriano et al. (2000), Little et al. (2001); Firinu et al. (2003); Shabana and Ouf (2003). Bystron (2005) and Manfreda et al., (2005) recorded similar results. On the other hand Hassan (1991), Hegazy (1999) and Ebraheem (2001) can not count $S$. aureus from ready to eat meat sandwiches. Sokari and Anozie (1990) suggested that the high level of contamination with $S$. aureus resulted from cross-contamination reflecting excessive hand contact with food stuffs.

As shown in Table 2 that illustrated the mean values of $S$. aureus count in the examined fast meat samples were $9.8 \times 10^{2} \pm 0.12 \times 10^{2}$, $1.2 \times 10^{3} \pm 0.24 \times 10^{2}$ and $8.3 \times 10^{2} \pm 0.09 \times 10^{2} \mathrm{CFU} / \mathrm{g}$ in shawarma, sausage and beef burger, respectively.

Statistically, there are significant differences between shawarma, beef burger and sausage, the later is higher in its $S$. aureus count than the others. These results are nearly agree with El-Daly (1983); Hoshyar, et al. (1984). Ayaz, et al. (1985) and Morshdy, et al. (1986). Lower findings achieved by Soliman (1988), Nassar (1988), Refaie and Moustafa (1990) and Daif (1996), while more than those obtained by ElSherbeeny et al. (1985), Fathi (1988) and Little et al. (2001). In this respect, Frazier and Westhaff (1978) reported that the growth of $S$. 
aureus in cooked or sterilized food is better than in raw foods if contamination occurs after manufacture and also they reported that the risk of $S$. aureus in burger is relatively low compared to the volume of burger eaten, this may be due to burger is usually cooks well.

Outbreaks could be resulted when processed or cooked meat has been improperly handled and mistreated in food processing plants and/or catering and food service establishments (ICMSF, 1980). Zein El-Abdin et al. (1992) reported that the increase in the bacterial counts of meat meals during distribution in aluminum dishes could be attributed to the holding temperature.

The results in Table 3 showed that the highest frequency distribution for shawarma and beef burger lies within the range of $10^{2}-10^{3} \mathrm{~S}$. aureus/g., while that of sausage samples was within $10^{3}-10^{4}$. Wieneke et al. (1993) recorded that meat and meat products were the vehicles of $75 \%$ of incidents of food poisoning with ham and chickens implicated, in the United Kingdom, (1969-90) and the level of S. aureus present in food ranged from no viable cells detected to $1.5 \times 10^{10}$ C.F.U./g. with a median of 3 X $10^{7}$ C.F.U./g. Wamola (1992) stated that the handling and preparation of food when in correct manner can reduce the level of microbial contamination thereby enhancing shelf life and he added that, certain foods carry a higher risk of microbial contamination than others. Little et al. (2001) isolated S. aureus from ready-to-eat burger with a level of $10^{2} \mathrm{CFU} / \mathrm{g}$, while Elmal et al. (2005) could detect S. aureus in fast beef doner kebabs in counts $<10^{2}$ to $10^{4} \mathrm{CFU} / \mathrm{gm}$. In this respect Fernandez et al. (2006) evaluated the effect of storage time and temperature on the microbiological quality of meat burger. They determined $S$. aureus in the burger samples and stated that fast food restaurant must follow the international standards.

As shown in Table 4 the results illustrated that the incidence of enterotoxins produced by $S$. aureus in shawarma was $37.5 \%$, where 3 strains belonged to type A. In sausage, 5 (45.5\%) of the recorded strains were enterotoxigenic where 2 of them were type A enterotoxin and the other 3 strains were enterotoxins AD. Four enterotoxigenic strains were obtained from beef burger samples $(44.5 \%)$ and were identified as 2 type $\mathrm{AB}$ and 2 type $\mathrm{ABCD}$ staphylococcal enterotoxins. These results agree with those obtained by Adesiyun (1984) who detected enterotoxins from ready-to-eat beef S. aureus isolates (43.3\%). The author stated that beef isolates of $S$. aureus were the most frequently toxic than other food products and may pose a health hazard with high incidence of enterotoxin type D. Bergdoll (1989) reported that S. aureus 
causes food poisoning by the production of one or more heat stable extracellular toxins, responsible for the symptoms of the disease, time of onset and severity of symptoms depend on the amount of toxin consumed and individual susceptibility. The enterotoxins produced at detectable levels (> $0.1 \mathrm{ng} / \mathrm{gm}$ ) in foods occurs only when growth reaches approximately $10^{6} \mathrm{CFU} / g m$ (Robbins et al., 1974 and Evenson et al., 1988).

The summarized results recorded in Table 4 nearly agree with those obtained by Adesiyun (1984); Rosec et al. (1997); Holeckova et al. (2002); Firinu et al. (2003) and Bystron (2005). Lower findings were achieved by Kumar et al. (2001) and Manfreda et al. (2005). It was found also that enterotoxin type A (SEA) is the most frequently followed by enterotoxin type D (SED) such results go parallel with the results of Minor and Marth (1972); Helena-Lopes et al. (1993) and Erol and Iseri (2004), they reported that staphylococcal enterotoxins A (SEA) and $\mathrm{D}$ (SED) being the most responsible for the majority of staphylococcus food poisoning. However, there is no relation between the enterotoxigenicity and the other biochemical charcateries (Bystron et al., 2002). On the other hand, the direct extraction of staphylococcal enterotoxins from the food samples revealed negative results (not detectable). Halpin-Dohnalek and Marth (1989) stated that enterotoxins can cause food poisoning are produced by about one-third (1/3) of the coagulase positive strains of $S$. aureus and the production of enterotoxigns is affected by the nutritional quality and $\mathrm{pH}$ of the substrate, temp., atmosphere, sodium chloride, water activity, other chemicals and competing microorganisms. It is benefit to mention that the reversed passive Latex agglutination assay (RPLA) for staphylococcal enterotoxins detection is a method based on the specific antibodies directed to the enterotoxins and characterized by its accuracy and easy to use. Bergdoll (1990) stated that the detection of $S$. aureus enterotoxins in food requires much more sensitive methods than those required for the determination of enterotoxigenicity of strains, and the quantity of enterotoxin present in foods involved in food poisoning outbreaks vary from less than $1 \mathrm{ng} / \mathrm{gm}$ to greater than $1 \mu \mathrm{g} / \mathrm{gm}$ food.

Considering the importance and public health hazard of $S$. aureus organism recovered from fast food (ready-to-eat meat sandwiches), Longree and Blacker (1971) reported that preparing and serving food to the public is a very important obligation that can only be fulfilled if every one in the establishment understand food hygiene, applying sanitary measures at every stage of the operation. Furthermore, ICMSF 
(1988) stated that cooked meat should not be touched by hands or by equipments that have come in contact with raw meat equipments that have come in contact with raw meat, raw products should be separated from cooked products to avoid cross-contamination.

To safe the ready-to-eat sandwiches sold in fast food services it must be focus on prevention of contamination and multiplication of microbes and production of toxins. Food should not be prepared long in advance of consumption (Bryan et al., 1992). Cooking usually give time temperature exposures that would have been lethal for vegetative form of food borne pathogens. On the other hand, holding of food provide time temperature exposures conductive to microbial growth, particularly in food helds overnight and large populations of aerobic organisms including $S$. aureus and others were recovered from these food. So, time temperature had variable effect of killing the microorganism but heat stable toxins still not affected (Jermini et al., 1997; Pepe et al., 2006).

In conclusion, it can be achieved from the obtained data that fast meat products (sandwiches) have the potential to cause staphylococcal intoxication to consumers. So, the rules of health agencies must reach to all workers in such field especially street vendors and fast food takeaway restaurants besides safety programs for safe food preparation drawn by WHO (1989) should be followed and effective preventive measures must be authorized and applied to safe the consumer health.

\section{REFERENCES}

Adesiyun, A.A. (1984): "Enterotoxigenicity of Staphylococcus aureus strains isolated from ready-to-eat foods." J. Food Prot., 47: 338.

Alkanahl, H.A. and Gasim, Z. (1993): "Food borne diseases incidents in the Eastern Province of Saudi Arabia, A five-year, summary, 1982-1986." J. Food Prot., 55 (1): 84-87.

APHA "American Public Health Association" (1992): "Compendium of Methods for the Microbiological Examination of Foods." $3^{\text {rd }}$ Ed., APHA Technical Committee on Microbiological Methods for Foods, Washington D.C., USA.

Ayaz, M.; Othman, R.A.; Bahareth, T.O.; Al-Sogair, A.M. and Sawaya, W.N. (1985): "Microbiological quality of shawarma in Saudi Arabia." J. Food Prot., 48 (9): 811-814.

Bailey, W.R. and Scott, F.G. (1990): "Diagnostic Microbiology." $8^{\text {th }}$ Ed., C.V. Mosby Comp., Saint Louis. 
Bergdoll, M.S. (1989): "Staphylococcus areus in: Bacterial Food borne Pathogens." Editor, Doyle, M.P. Marcel, Dekker Press, New York.

Bergdoll, M.S. (1990): "Analytical methods for S. aureus." International J. Food Microbiol., 10: 91.

Bryan, F.L. (1978): "Factors that contribute to outbreaks of foodborne disease." J. Food Prot., 41: 816-827.

Bryan, F.L. (1988): "Risks associated with vehicles of foodborne pathogens and toxins." J. Food Prot., 51: 498-508.

Bryan, F.L. (1992): "Hazard analysis critical control point evaluation. A guide to identify hazards and assessing risks associated with food preparation and storage." World Health Organization, Geneva.

Bryan, F.L.; Teufel, P.; Riaz, S.; Roohi, S.; S.; Qudar, F. and Malik, Z. (1992): "Hazards and critical control points of vending operations at a railway station and a bus station in Pakistan." J. Food Prot., 55 (6): 534.

Bystron, J.; Kosek, P.K. and Molenda, J. (2002): "Occurrence of enetrotoxigenic staphylococci in white raw sausage." Medycyna Weterynaryjna, 58 (2): 995-997.

Bystron, J.; Bania, J.; Molenda, J.; Kosek, P.K. and Korzekwa, K. (2005): "Distribution of staphylococcal enterotoxin genes among Staphylococcus aureus isolates from food and humans." Medycyna Weterynaryjna, 61 (11): 1270-1273.

Daif, E.A. (1996): "Sanitary status of meat of the students of El-Azher University, Assiut branch." M.V.Sc. Thesis, Meat Hygiene Dept., Fac. Vet. Med., Assiut University.

Donnelly, C.B.; Leslie, J.E.; Black, L.A. and Lewis, K.H. (1967): "Serological identification of enetrotoxigenic staphylocci from cheese." Appl. Microbiol., 15: 1382.

Ebraheem Ghada, M.M. (2001): "Ready-to-eat meat sandwiches as a source of potential pathogens in Assiut city." M.V.Sc., Fac. Vet. Med., Assiut University.

El-Daly, E.A. (1983): "Sanitary status of meat serving establishment." Ph.D. Thesis, Cairo University.

Elmal, M.; Ulukaml, Z.; Tuzcu, M.; Yaman, H. and Cavl, P. (2005): "Microbiological quality of beef doner kebabs in Turkey." Archiv-Fur-Lebensmittel Hygiene, 56 (2): 32-34. 
El-Sherbeeny, M.R.; Saddik, M.F. and Bryan, F.L. (1985): "Microbiological profiles of food served by street vendors in Egypt." Int. J. Food Microbiol., 216: 355.

Erol, I. and Iseri, O. (2004): "Staphylococcal enterotoxins." Ankara Universitesi Veteriner Fakultesi Dergisi, 51 (3): 239-245.

Evenson, M.L.: Hinds, M.W.; Bernstein, R.S. and Bergdoll, M.S. (1988): "Estimation of human dose of staphylococcal enterotoxin A from a large outbreak of staphylococcal food poisonings." Int. J. Food Microbiol., 7: 311-316.

FAO (1992): "Meat and meat products in human nutrition in developed countries." United Nations. Rome, Food and Nutrition paper 53: 43.

Fathi, S.M. (1988): "Sanitary status of meat serving establishment in Assiut." Ph.D. Thesis, Fac. Vet. Med., Assiut University.

Fernandez, R.A.; Izquierdo, C.P.; Valero, L.K.; Allora, C.M.; Pinero, G.M. and Garcia, U.A. (2006): "Effect of time and storage temperature on microbiological quality of hamburger meat." Revista - Cientifica, Facultated - deCiencias - Veterinarias, Universidad - del-Zulia, 16 (4): 428-437.

Firinu, A.; Virigilo, S.; Mula, G.; Poggiu, A.; Zuccon, F.; Pirino, T.; Sias, S.; Normanno, G.; Dambrosio, A.; Quaglia, N.C. and Celano, G.V. (2003): "Detection and enetrotoxigenic characterization of Staphylococcus aureus from animal food products." Industrie Alimentari, 42 (426): 613-616.

Flandrois, J.P. and Carret, G. (1981): Zbl. Bakht. Hug. Orig., A: 251: 1171-1176. Cited after Kadry, R.M. (1990).

Frazier, W.C. and Westhaff, D.C. (1978): "Foodborne infection and intoxication: Bacterial in Food Microbiology". 3 rd Ed., pp. 432-438, McGrow-Hill Book Company, New York, London, Toronto.

Halpin-Dohnalek, M.I. and Marth, E.H. (1989): "Staphylococcus aureus: Production of extracellular compounds and behaviour in foods." J. Food Prot., 52 (4): 267-282.

Hassan, A.I. (1991): "Sanitary improvement of passengers meals ion air catering plant." Ph.D.. Thesis, Fac. Vet. Med., Cairo University.

Hegazy, Salwa, R.S. (1999): "Risk street vending on public health." M.V.Sc., Thesis, Meat Hygiene, Fac. Vet. Med., Cairo University. 
Helena-Lopes, R.; Noleto, A.L.S.; Las Heras, M.D. and Bergdoll, M.S. (1993): "Selective enterotoxin production in foods by Staphylococcus aureus strains that produce more than one enterotoxin." J. Food Prot., 56 (6): 538-540.

Holeckova-Moleckova, B.; Holoda, E.; Fotta, M.; Kalinacova, V.; Dianovsky, J.; Sivikova, K. and Piesova, E. (2002): "Enterotoxin production by Staphylococcus aureus in relation to food hygiene and ecology." Folia Veterinaria; 46 (2): 32-33.

Hoshyar, D.F.; Muhaddin, M.O. and Said, N.A. (1984): "A microbiological study of some roasted meats at Aski-Kalak retail restaurants." J. Zenco, 2 (3): 57 (cited after Hagazy, 1999).

ICMSF (International Commission on Microbiological Specification for Food), (1980): "Microbiological Ecology of foods. 1. Factors affecting life and death of microorganisms." Academic Press, London.

ICMSF (International Commission on Microbiological Specification for Food), (1988): "Microorganisms in food. 4. Application of the hazard analysis critical control point (HACCP) system to ensure microbial safety and quality." Blackwell, Oxford, London.

Jermini, M.; Bryan, F.L.; Schmitt, R.; Mwandwe, C.; Mwenya, J.; Zyuulu, M.H.; Chilufya, E.N.; Matoba, A.; Hakalima, A.T. and Michael, M. (1997): "Hazards and critical control points of food vending operations in a city in Zambia." J. Food Prot., 60 (3): 288-299.

Kadry, R.M. (1990): "Enetrotoxigenic strains of staphylococci in markets fishes." M.V.Sc. Thesis, Food Hygiene and Control Dept., Fac. Vet. Med., Cairo University.

Korpysa, W.; Rola, J.G. and Osek, J. (2005): "Staphyloccal enterotoxins and their detection in milk and milk products." Medycyna Weterynaryjna, 61 (6): 633-636.

Kumar, J.K.; Sharma, A.K. and Kulkarmi, P.R. (2001): "Survey of Indian foods for Staphylococcus aureus." Ind. Vet. J., 78 (10): $11-14$.

Little, C.L.; Gillespie, I.A. and Mitchell, R.I. (2001): "Microbiological examination of ready-to-eat burger sampled anasiymously at the point of sale in the united Kingdom." Communicable Disease and Public Health, 4 (4): 293-299. 
Longree, K. and Blacker, G.G. (1971): "Sanitary techniques in food service." John Wiley and Sons, Inc., New York.

Manfreda, G.; Mioni, R. and Cesare, A.de (2005): "Surveillance and characterization of enterotoxigenic staphylococci in foods of animal origin collected in the Veneto region." Vet. Res. Comm., 29 (2): 331-333.

Marchant, I.M. and Parker, R.A. (1983): "Veterinary Bacteriology and Virology." $7^{\text {th }}$ Ed., Indian Ed., Iowa State University.

Minor, T.E. and Marth, E.H. (1972): "Fate of Staphylococcus aureus in cultured butter milk, Sour cream and yoghourt during storage." J. Milk Food Technology, 35: 302-306.

Morshdy, A.; El-Daly, E.; Saleh, E. and El-Atabawy, A. (1986): "Sanitary status of ready-to-eat shawarma." Dept. of Food Control, Fac. Vet. Med., Zagazig Vet. J., XIV, 1: 1.

Nassar, A. (1988): "Sanitary status of meat meals in Assiut University Hospitals." M.V.Sc. Thesis, Fac. Vet. Med., Assiut University.

Oda, T.; Ohkuboty, T.; Nagai, M.; Nishimoto, Y. and Ohmaruk, K. (1979): "Detection of staphylococcal enterotoxins in foods by reversed passive latex agglutination test." Ann. Rep. Fukuak City Hyg. Lab., 4: 33-37.

Park, C.E. and Szabo, R. (1986): "Evaluation of the reversed passive Latex agglutination (RPLA) test kits for detection of staphylococcal enetrotxoins A, B, C and D in foods." Canad. J. Microbiol., 32: 723-727.

Pepe, O.; Blaiotta, G.; Bucci, F.; Anastasio, M.; Aponte, M. and Villani, F. (2006): "Staphylococcus aureus and staphyloccal enterotoxin A in breaded chicken products: Detection and behaviour during the cooking process." Applied and Environmental Microbiology, 72 (11): 7057-7062.

Refaie, R.S. and Moustafa, S. (1990): "Microbial quality of shawarma in Assiut." Assiut Vet. Med. J., 24 (47): 153.

Robbins, R.; Sara, G. and Bergdoll, M. (1974): "Detecting the enterotoxigenicity of $S$. aureus strains." Appl. Microbiol., 28: 946.

Rosec, J.P.; Guiraud, J.P.; Dalet, C. and Richard, N. (1997): "Enterotoxin production by staphylococci isolated from foods in France." Int. J. Food Microbiol., 35 (3): 213-221.

Soriano, J.M.; Rico, H.; Molto, J.C. and Manes, J. (2000): "Microbial evaluation of Spanish potato owelette and cooked meat samples in University restaurants." J. Food Prot., 63 (9): 1273. 
Shabana, E.S.S. and Ouf, Jehan M. (2003): "Hygienic quality of chicken shawarma." J. Egypt. Vet. Med. Assoc., 63 (5): 73.

Shingaki, A.E.; Igarashi, H.; Fujikawa, H.; Vshioda, H.; Terayarm, T. and Sakai, S. (1981): "Study on reversed passive latex agglutination for the detection of staphylococcal enterotoxins A, B and C." Annu. Tokyo Met. Lab. Pub. Hlth., 32: 128.

Sokari, T.G. and Anozie, S.O. (1990): "Occurrence of enterotoxin producing strains of Staphylococcus aureus in meat and related samples from traditional markets in Nigeria." J. Food Prot., 53 (12): 1069-1070.

Soliman, M.R. (1988): "Sanitary status of ready-to-eat meat." M.V.Sc. Thesis, Fac. Vet. Med., Cairo University.

Wamola, I.A. (1992): "Microbial contamination of commercial food products: factor fiction." East African Medical Journal, 69 (3): 519-531.

WHO (World Health Organization) (1989): "The WHO golden rules for safe food preparation." News litter, Institute of Veterinary Medicine, Robert Von Ostertag Institute, FAO/WHO Collaborating Center for Research and training in Food Hygiene and Zoonoses, Berlin West

Wieneke, A.A. (1974): "Enterotoxin production by strains of Staphylococcus aureus isolated from foods and human beings." J. Hygiene, 73 (2): 255-262.

Wieneke, A.A.; Robberts, D. and Gilbert, R.J. (1993): "Staphylococcal food poisoning in the United Kingdom, 1969-1990." Epidemiology and Infection, 110 (3): 519-531.

Zein El-Abdien, Y.; El-Mossalami, E.; Hamdy, M.; Yassien, N. and Hassan, A. (1992): "Minimization of bacterial load of meat aviation centering." pp. $823,3^{\text {rd }}$ World Congress, Food borne Infections and Intoxication (16-19 June) Berlin. 